\title{
Contribution of ICT Literacy and Teachers Work Ethic on the Quality of Distance Education in State Junior High Schools of Sukoharjo Sub-District
}

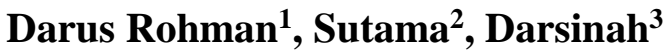 \\ ${ }^{1,2,3}$ Universitas Muhammadiyah Surakarta, Indonesia \\ darusrohman52@guru.smp.belajar.id,sutama@ums.ac.id,darsinah@ums.ac.id
}

\begin{abstract}
The aim of this study is to investigate the effect of ICT literacy and teacher work ethic on the quality of distance education in Sukoharjo Sub-District state senior high schools. The sample included 200 teachers from state junior high schools in Sukoharjo Sub-District. A questionnaire is used to collect data. Multiple linear regression analysis was used to analyze the data in this study. Previously, validity tests, reliability tests, and classical assumption tests were used to analyze data. The findings indicated that: 1) Information and communication tachnology literacy contributed considerably to the quality of remote education. This is evident from the T test result of 4,401, p of 0.000 0.05. 2) The work ethos of teachers has a substantial beneficial effect on the quality of distance education. This is established using the T test of 3,486, with a $p$ value of 0.0010.05. Advice based on the findings of this study may be utilized as a guideline for teachers' ICT skills training, as well as a critical foundation for the methodical construction, enhancement, and sustainability of distance education.
\end{abstract}

Keywords

information and communication technology literacy; work ethic; quality of distance education

\section{Introduction}

Sihombing and Nasib (2020) stated that the Covid-19 pandemic caused everyone to behave beyond normal limits as usual. Ningrum et al (2020) stated that the impact caused by this virus also approached Indonesia and its entire region. Since the outbreak of Corona, or Covid-19, in Indonesia in March 2020, the Indonesian government and Ministry of Education and Culture have enforced a home-based learning policy on students in order to contain the virus' spread. Remote learning models are used to conduct policy learning from home. This type of education might take place concurrently or at various periods (Prawiyogi, A. G., et al. 2020).

The situation is directly related to the purpose of national education as defined in Republic of Indonesia Law No. 20 of 2003 on the National Education System, which states that education is an effort to help students actively develop their potential for religious spiritual strength, self-control, personality, intelligence, Noble character, and skills necessary for themselves, society, nation, and country.

Education focuses on all aspects of human existence that are useful, including physical activity of the mind, as well as mental sharpness and conscience. One of the consequences of the abrupt change in the style of instruction is the development of numerous reports or complaints about the problems encountered by students and parents (Mulyana et al., 2020) Thus, education is an excellent vehicle for transforming humans into individuals who benefit both themselves and others. Educational objectives are identical to the objectives of living persons and are not defined by others. Education is 
continuous, which implies it continues during one's life (Life Long Education). Thus, education occurs within the framework of multifaceted individual connections, both with the God, fellow people, nature, and even with themselves. Thus, education may be defined as a process of learning that occurs throughout a person's life, with the model and learning medium evolving in lockstep with the times.

Literacy Information and communication technology (ICT) is the capacity to produce and share in a variety of modes and forms: to cooperate and communicate more effectively, as well as to understand how and when to use appropriate digital technology to support the process. A critical component of enhancing the quality of education is the development of educational and learning technology. The employment of educator technology, or the different labels they use: technology for education, information technology (IT), or information and communication technology (ICT), is regarded to be one strategy for resolving the problem outlined above.

A teacher is a professional educator whose primary responsibility is to educate, to teach, to guide, to direct, to train, to assess, and to evaluate students in early childhood education, formal education, elementary education, and secondary education. To enhance the quality of teaching and learning, teachers should become proficient with computer programs in order to take advantage of existing technology and facilitate instruction. Human resources, infrastructure, hardware, and software all contribute to the implementation of information and communication technology (ICT). Implementation challenges in schools include the following: insufficient management employees with expertise in information technology, not all schools have supporting infrastructure, not all schools have comprehensive hardware in terms of both quality and quantity, and the original software is pricey (Bachtiar et al, 2008).

Because of the underlying attitude toward the direction or intensity of performance, the attitude toward work is the most recognized foundation. The manifestation of good work is evident when a person has a positive and reasonable attitude toward his or her work. Loving your own work is one way to demonstrate a positive attitude toward work (Prasasti, 2017).

The demands and responsibilities of teacher as the primary facilitator of education in the classroom are highly complex (Mertha et al., 2019). The work ethic is an identity requirement for ethical behavior in the pursuit of good and productive employment. Distance education is a type of structured learning that typically takes place outside of the classroom. As a result, specialist techniques in topic design, specialized learning techniques, specialized methods of communication via multiple media, and specialized organizational arrangements and administrations are required.

Professionalism An educator is critical in ensuring that students receive a highquality education through a variety of learning procedures. Professional development of educators has an effect on the quality of education. To increase the quality of education, the government has established training programs to enhance teachers' ability to perform their obligations, such as topic teacher associations and training in developing learning programs. In response to teacher professionalism demands, the government enacts Law No. 14 of 2005 Concerning Teachers and Lecturers. With the passage of the law, teachers are now classified as a profession alongside doctors, judges, and accountants, all of whom will get proportional compensation for their work. The teacher is a professional educator whose primary responsibility is to educate, teach, guide, direct, and train pupils in early childhood education, formal education, basic education, and secondary education. According to law No. 14 of 2005, the school is one of the facilitators in bringing it to fruition. Students were shaped at school to become better human beings, and teachers in 
public junior high schools in Sukoharjo Subdistrict actively participated in educating the nation's generation.

State senior high schools in Sukoharjo Subdistrict are generally schools that have the facilities and infrastructure necessary to support school learning completely; however, some facilities, such as the internet, are still limited; for example, the internet can only be accessed in computer rooms, teacher rooms, and school rooms. However, there are still challenges here. Teachers, particularly those responsible for media selection in the classroom, should be able to use creative learning media. Today, teachers are still predominately adopting static lecture methods, which contributes to students' declining enthusiasm in following the learning process.

Research on improving the quality of distance education has been carried out by (Mamahit, 2021) (Sugiran et al., 2016) regarding the use of various tools and media for distance learning (Purwanto et al., 2020) and Yuliani (2021) regarding the implementation of distance education and improving the quality of learning during the pandemic Covid-19 era.

To overcome these problems, the teachers should really improve the understanding of various learning methods so that teacher learning activities can apply various relevant media. Internet media is one of the most modern learning media in supporting the learning process in the Covid 19 pandemic era. On the background of the above context, this study investigated contribution of teachers' literacy and work ethic on the quality of distance education in state junior high schools of sukoharjo sub-district.

\section{Research Methods}

Correlational research is a type of study that employs correlational statistics to elucidate inter-variable relationships ( $r$ ). The square root of the correlation coefficient provides the variant defined (r-square) (Sutama, 2019: 47). This study employs a quantitative approach. The method gathered data by sending questionnaires to teachers in Sukoharjo sub-district. The questions were designed to characterize the contents of a specific piece of information or text (Herliandry et al., 2020). The sample for this study included 200 instructors from state junior high schools in Sukoharjo Sub-District. A questionnaire is used to collect data. The notion is based on numerous scholarly studies published during the Pandemic Covid-19 period about online learning. Scientific publications are sourced from worldwide and national journals, as well as a variety of additional sources. Multiple linear regression analysis was used to analyze the data in this study. Previously, validity tests, reliability tests, and classical assumption tests were used to analyze data.

\section{Results and Discussion}

Policies in complying with health protocols with the form of social distance and physical distances to minimize the spread of Covid-19 encourage all educational elements to activate the class even though the school closes. The spread of questionnaires to respondents can be done, then the data analysis calculation process can be done.

\subsection{Validity Test Results}

a. Validity Variable ICT Literacy Test (X1)

The following table presents the results of the test validity calculation for the ICT literacy variables: 
Table 1. Validity Variable ICT Literacy Test (X1)

Item-Total Statistics

\begin{tabular}{lcc}
\hline & $\begin{array}{c}\text { Corrected } \\
\text { Item-Total } \\
\text { Correlation }\end{array}$ & $\begin{array}{c}\text { Cronbach's } \\
\text { Alpha if Item } \\
\text { Deleted }\end{array}$ \\
\hline itemX1_1 & .763 & .917 \\
itemX1_2 & .627 & .925 \\
itemX1_3 & .842 & .913 \\
itemX1_4 & .841 & .913 \\
itemX1_5 & .679 & .922 \\
itemX1_6 & .581 & .926 \\
itemX1_7 & .877 & .911 \\
itemX1_8 & .688 & .921 \\
itemX1_9 & .610 & .925 \\
itemX1_10 & .716 & .920 \\
\hline
\end{tabular}

According to the table above, the statement (X1-1 to X1-10) from 10 items is declared legitimate due to the value of $r$ count (correct items total correlation $>r$ table $n$ $200=0.116$ ). To proceed with the investigation, the process of computing the assumption test can be continued.

\section{b. Teachers' Work Ethic (X2)}

The following table presents the validity test results for the teachers' work ethic variables:

Table 2. Validity Test Results of Teachers' Work Ethic Variables

\begin{tabular}{lrr}
\multicolumn{3}{c}{ Item-Total Statistics } \\
\hline & $\begin{array}{c}\text { Corrected } \\
\text { Item-Total } \\
\text { Correlation }\end{array}$ & $\begin{array}{c}\text { Cronbach's } \\
\text { Alpha if Item } \\
\text { Deleted }\end{array}$ \\
\hline itemX2_11 & .758 & .559 \\
itemX2_12 & .298 & .699 \\
itemX2_13 & .612 & .595 \\
itemX2_14 & .560 & .625 \\
itemX2_15 & .712 & .560 \\
\hline
\end{tabular}

According to the table above, the statements from X2-1 to X2-5) are valid because the value of $r$ counts (correct items total correaliation $>r$ table). As a result, the problem items can be used to describe the variables relating to the teachers' work ethic as study data.

\section{c. Quality of Distance Education (Y)}

The following table presents the validity test results for the quality of distance education variables: 
Tabel 3. Validity Test Results of Quality of Distance Education Variables Item-Total Statistics

\begin{tabular}{lrr}
\hline & $\begin{array}{c}\text { Corrected } \\
\text { Item-Total } \\
\text { Correlation }\end{array}$ & $\begin{array}{c}\text { Cronbach's } \\
\text { Alpha if Item } \\
\text { Deleted }\end{array}$ \\
\hline itemY_16 & .871 & .929 \\
itemY_17 & .829 & .931 \\
itemY_18 & .873 & .930 \\
itemY_19 & .694 & .936 \\
itemY_20 & .754 & .934 \\
itemY_21 & .871 & .929 \\
itemY_22 & .829 & .931 \\
itemY_23 & .873 & .930 \\
itemY_24 & .694 & .936 \\
itemY_25 & .754 & .934 \\
itemY_26 & .209 & .956 \\
\hline
\end{tabular}

According to the table above, statements containing one item (item Y-16 to Y-25) are declared legitimate due to the value of $r$ (correct items total correaliation $>r$ table). Thus, as research data, the item of the question can be utilized to reflect the varying quality of distance education.

\subsection{Reliability Test Results}

The reliability test calculation results are presented in the appendix below, namely:

Table 4. Reliability Test Results

\begin{tabular}{lccl}
\hline \multicolumn{1}{c}{ Variable } & $\begin{array}{c}\text { Value of } \\
\text { Cronbach's } \alpha\end{array}$ & Limit Value & Decision \\
\hline $\begin{array}{l}\text { ICT literacy } \\
\text { Teachers' work ethic }\end{array}$ & 0,927 & 0,700 & reliable \\
$\begin{array}{l}\text { Distance education } \\
\text { quality }\end{array}$ & 0,703 & 0,700 & reliable \\
\hline
\end{tabular}

The reliability test revealed Cronbach's values of $0.927>0.700$ for ICT literacy factors, $0.703>0.700$ for teacher work ethic variables, and $0.940>0.700$ for distance education quality variables. These findings imply that the data on the variable of ICT literacy, the teacher's work ethic, and the variable of long-distance education are dependable and deserving of being employed as data collection instruments.

\subsection{Assumption Test Results}

\section{a. Data Normality Test}

The results of the normality test calculation are represented by the KolmogorovSmirnov normality test, which is presented in the table below: 
Table 5. Normality Test

One-Sample Kolmogorov-Smirnov Test

\begin{tabular}{llr}
\hline & & $\begin{array}{r}\text { Unstandardiz } \\
\text { ed Residual }\end{array}$ \\
\hline $\mathrm{N}$ & Mean & 200 \\
Normal Parameters ${ }^{\mathrm{a}, \mathrm{b}}$ & Std. & $0 \mathrm{E}-7$ \\
& Deviation & 6.74031423 \\
Most Extreme & Absolute & .258 \\
Differences & Positive & .134 \\
Kolmogorov-Smirnov Z & Negative & -.258 \\
Asymp. Sig. (2-tailed) & & 3.646 \\
\hline
\end{tabular}

a. Test distribution is Normal.

b. Calculated from data.

As demonstrated in the table above, the significant value of Kolmogorov Smirnov is $0.320(0.320>0.05)$, indicating that the data is regularly distributed. It can be calculated further at the next stage.

\section{b. Multicollinearity Test}

The multicollinearity test results are represented by the VIF value of the regression calculation, which is presented in the table below:

Table 6. Multicollinearity Test Results

\begin{tabular}{llccl}
\hline No & Variable & VIF value & $\begin{array}{c}\text { Limit } \\
\text { Value }\end{array}$ & Description \\
\hline 1 & ICT Literacy & 1.004 & 10 & $\begin{array}{l}\text { There is no } \\
\text { multicollinearity }\end{array}$ \\
2 & Teachers' Work Ethic & 1.004 & 10 & $\begin{array}{l}\text { There is no } \\
\text { multicollinearity }\end{array}$ \\
\hline
\end{tabular}

Dependent variable: quality of long distance education

The results of multicollinearity tests indicate that the magnitude of each variable's VIF is less than 10, implying that there are no multicollinearities.

c. Heteroscedasticity Test

The following visual illustration presents the results of the heteroscedasticity test: 


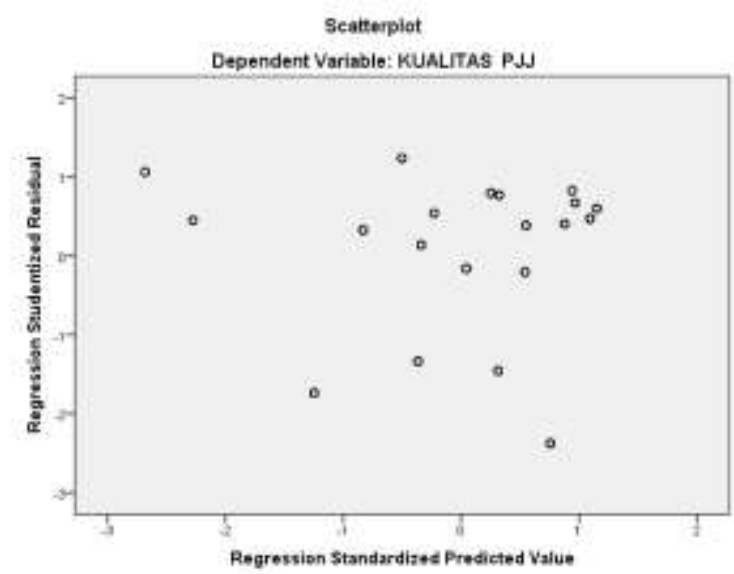

Figure 1. Heterocedasticity Test

The test demonstrates that the data are distinct and that there are no symptoms of heteroscedasticity.

\section{d. Autocorrelation Test}

The autocorrelation test results are presented in the table below:

Table 7. Autokorelasi

\begin{tabular}{l}
\multicolumn{2}{c}{ Model Summary } \\
\hline Model Durbin-Watson \\
1 \\
\hline a. Predictors: (Constant), ETOS \\
KERJA GURU, LITERASI TIK \\
b. Dependent Variable: \\
KUALITAS PJJ
\end{tabular}

Durbin-value Watson's of 1.829 indicates that it is approaching the value of two (2). This demonstrates that this research is free of both positive and negative autocorrelation issues.

\subsection{Descriptive Statistics}

Description of Respondents Based on Gender

The following table and figure are the data description of respondents based on gender:
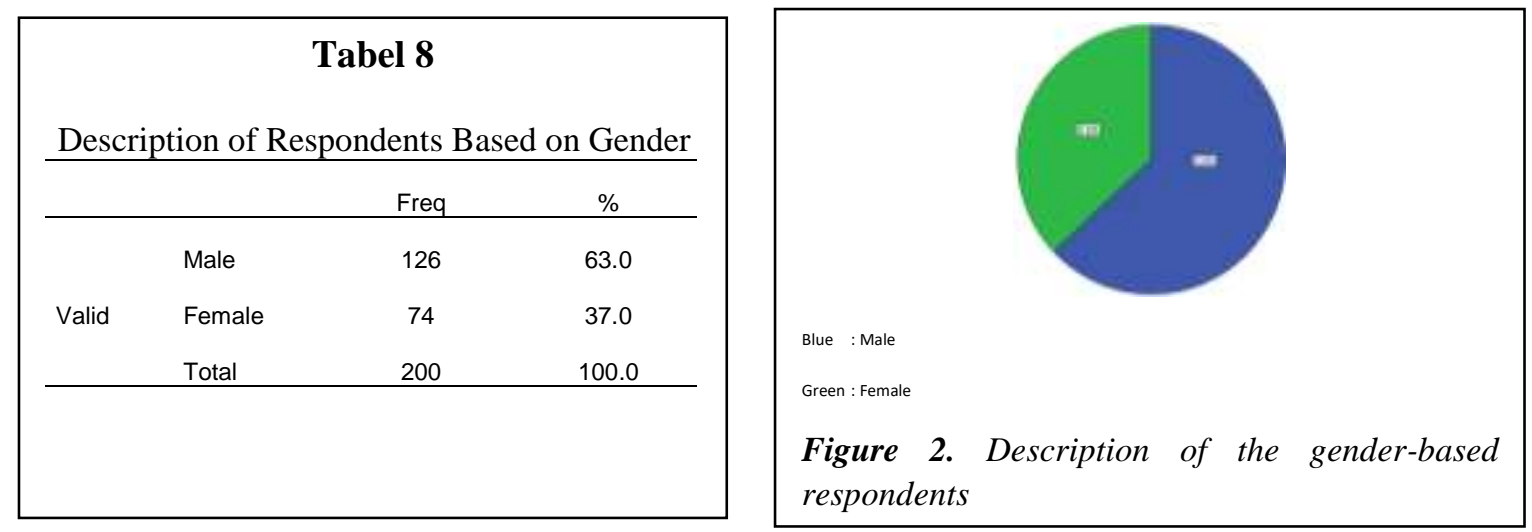
The data collection revealed that the respondents in this study were state senior high school teachers in Sukoharjo Regency, with 126 people $(63 \%)$ being male and 74 people (37\%) being female. Furthermore, the following image presents respondent data by gender:

\subsection{Description of Respondents Based on Age}

The following table and figure are the data description of respondents based on age:

\begin{tabular}{|cccc|}
\hline \multicolumn{4}{c}{ Table 9 } \\
Age \\
\hline & Freq & $\%$ \\
\hline \multirow{4}{*}{ Valid } & 2 & 1.0 \\
& $20-25$ years old & 48 & 24.0 \\
& $26-30$ years old & 150 & 75.0 \\
& $>30$ years old & 200 & 100.0 \\
\hline & Total & & \\
\hline
\end{tabular}

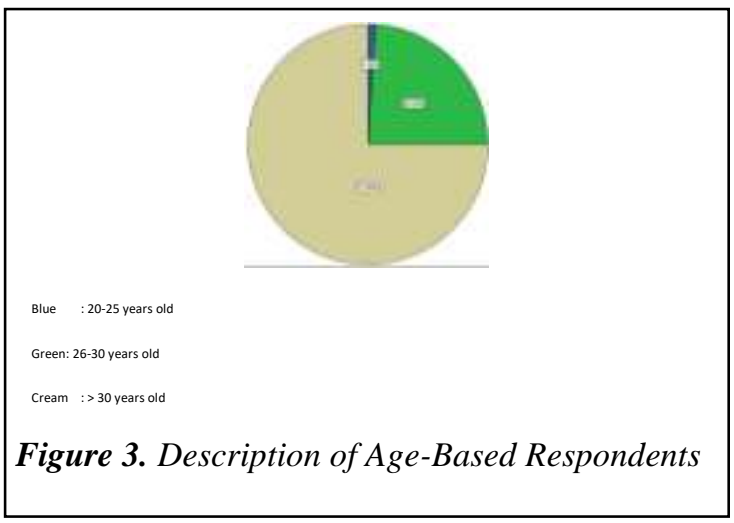

The data collection revealed that the respondents in this study were public junior high school teachers in Sukoharjo Regency. Twenty-five to twenty-five year old respondents included two people or 1\%, 26- to 30-year-old respondents comprised 48 people or $24 \%$, and over 30-year-old respondents comprised 150 people or $75 \%$. Additionally, respondents might be grouped according to their age in the figures adjacent.

Description of Respondents Based on Length of Internet Use in One Day

The following table and figure are the data description of respondents based on length of internet use in one day:

\begin{tabular}{|c|c|c|c|}
\hline \multicolumn{4}{|c|}{$\begin{array}{c}\text { Table 10 } \\
\text { Description of Respondents based on Length of } \\
\text { Internet Use in One Day }\end{array}$} \\
\hline & & Freq & $\%$ \\
\hline \multirow{5}{*}{ Valid } & 5 - 30 minutes & 22 & 11.0 \\
\hline & $30-60$ minutes & 110 & 55.0 \\
\hline & 60 - 90 minutes & 28 & 14.0 \\
\hline & $>90$ minutes & 40 & 20.0 \\
\hline & Total & 200 & 100.0 \\
\hline
\end{tabular}

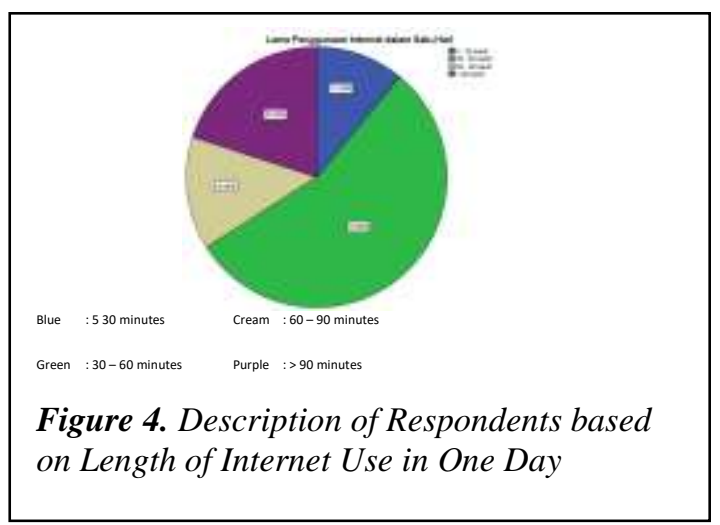

The data collection revealed that the respondents in this study were state junior high school teachers in Sukoharjo Regency, based on the length of internet use in one day. In a single day, respondents used the internet for an average of 5-30 minutes (21 people or 11 $\%$ ), 30-60 minutes (110 people or $55 \%$ ), 60-90 minutes (28 people or $14 \%$ ), and more than 90 minutes (40 or $20 \%$ ). Furthermore, respondents' data based on the length of internet use in one day can be presented in the table and the figure above. 


\subsection{Description of Respondents Based on The Benefits of Internet Use}

The following table and figure are the data description of respondents based on the benefits of internet use:

\begin{tabular}{|lcc|}
\hline \multicolumn{4}{c}{ Table 11 } & \\
The benefits of Internet Use & \\
\hline \multicolumn{4}{c}{ Freq } & $\%$ \\
\hline Information source or reference & 2 & 1.0 \\
Valid & 12 & 6.0 \\
Checking E-Mail or communication & 62 & 31.0 \\
Networking & 124 & 62.0 \\
A,B,C are correct & 200 & 100.0 \\
\hline Total & & \\
\hline
\end{tabular}

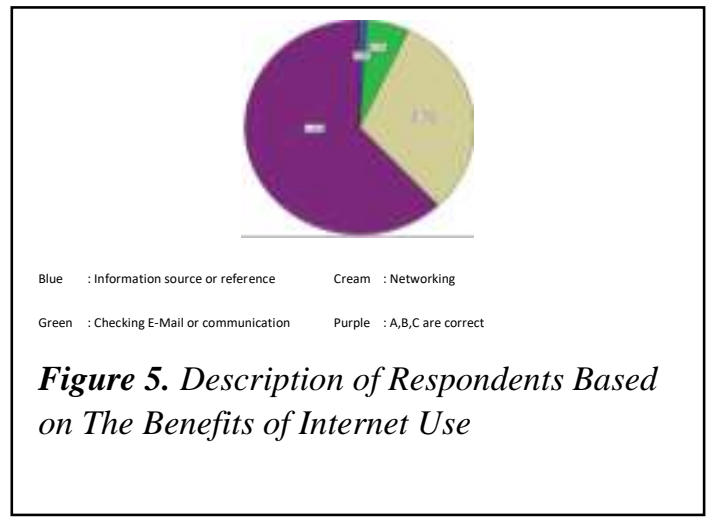

According to the benefits of internet use, the respondents in this study were state junior high school teachers in Sukoharjo Regency. The benefits of internet use as a source of information or references were mentioned by 2 respondents (1\%). The benefits of internet as a tool for checking e-mail or communication were mentioned by 12 respondents (6\%). The benefits of internet use as a tool for networking were mentioned by 62 respondents $(31 \%)$. The benefits of internet as a tool of information or reference, as a tool for checking E-Mail or communication, as a tool for networking were mentioned by 124 respondents $(62 \%)$. Furthermore, the respondent data can be presented in the table and figure adjacent above based on the benefits of internet use.

\subsection{Description of Respondents Based on Types of Social Networking Application}

The following table and figure are the data description of respondents based on types of social networking application:

\begin{tabular}{|cccc|}
\hline \multicolumn{4}{c}{ Table 12 } \\
Types of Social Networking Application \\
\hline & Freq & Percent \\
\hline \multirow{4}{*}{ Valid } & Facebook & 20 & 10.0 \\
& Instagram & 6 & 3.0 \\
& Google & 174 & 87.0 \\
& Total & 200 & 100.0 \\
\hline & & & \\
\hline
\end{tabular}

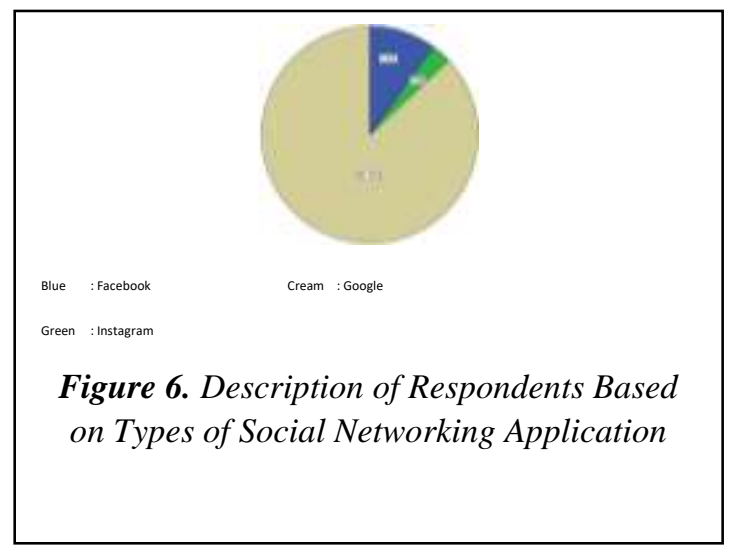

According to the description based on types of social networking application, the respondents in this study were state junior high school teachers in Sukoharjo Regency. 20 respondents or 10\% use Facebook. 6 respondents or 3\% use Instagram. 174 respondents or $87 \%$ use Google. Furthermore, the respondents can be presented in the table and figure adjacent. 


\subsection{Description of Respondents Based on Learning Information}

The following table and figure are the data description of respondents based on learning information:

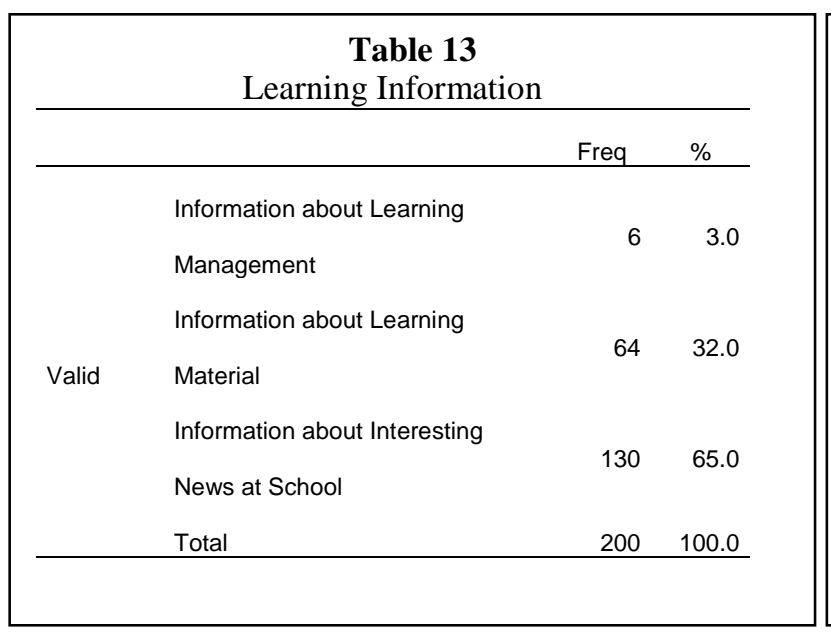

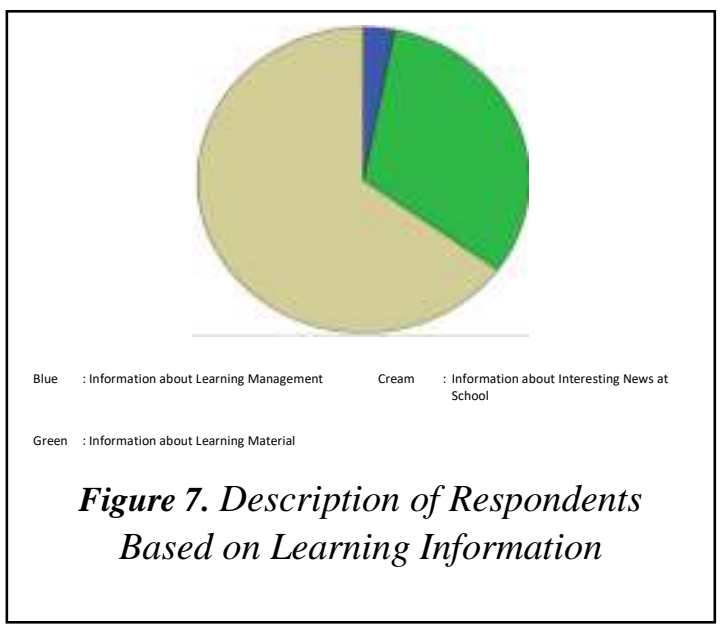

Respondents in this study were state junior high school teachers in Sukoharjo Regency. Learning information was received from respondents concerning learning management from 6 respondents or 3\%, learning material from 64 resondents or 32\%, and interesting news at school from 130 respondents or $65 \%$. Furthermore, respondents based on learning information can be presented in the table and the figure adjacent.

Description of Respondents Based on Social Media Frequency as an Information Source. The following table and figure are the data description of respondents based on social media frequency as an information source:

\begin{tabular}{|c|c|c|c|}
\hline \multicolumn{4}{|c|}{$\begin{array}{l}\text { Table } 14 \\
\text { Social Media Frequency as an information } \\
\text { source } \\
\end{array}$} \\
\hline & & Freq & Percent \\
\hline \multirow{4}{*}{ Valid } & $<2$ times & 37 & 18.5 \\
\hline & $2-5$ times & 84 & 42.0 \\
\hline & $>5$ times & 79 & 39.5 \\
\hline & Total & 200 & 100.0 \\
\hline
\end{tabular}

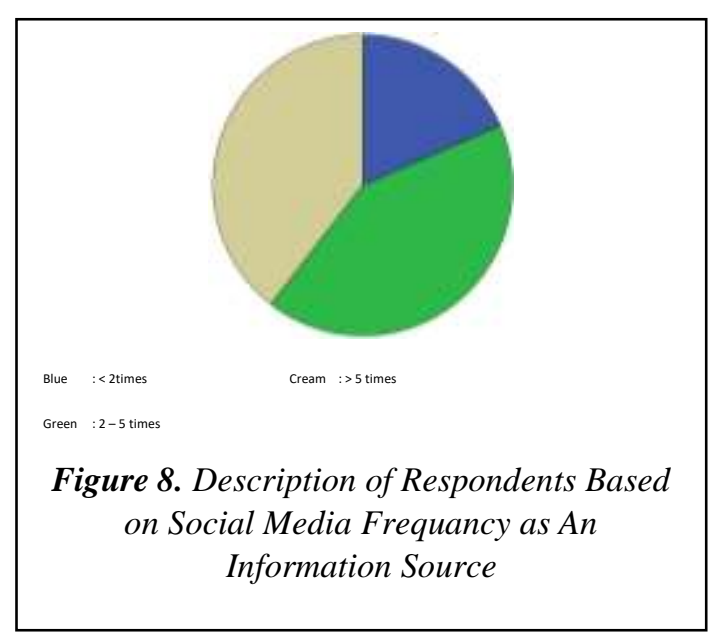

According to data collected from respondents in this study, notably state junior high school teachers in Sukoharjo Regency, the frequency of social media use among respondents is less than 2 times as many as 37 people or $18.5 \%$ the frequency of social media use among respondents is between 2 and 5 times as many as 84 people or $42 \%$. The frequency of social media use among respondents is more than 5 times as many as 79 people or $39.5 \%$. Furthermore, respondents' frequency of social media use can be presented in the table and the figure adjacent. 


\subsection{Hypothesis Testing and Discussion}

a. Multiple Linear Regression Analysis

The multiple linier regression analysis is used to determine the influence of ICT literacy and teacher work ethic on the quality of distance education in public junior high school teachers in Sukoharjo Regency. The results of the equation are described as follows:

Table 15. Multiple Linear Regression Test Results

\begin{tabular}{lrrr}
\hline \multirow{2}{*}{ Variable } & \multicolumn{3}{c}{ Unstandardized } \\
& \multicolumn{1}{c}{ Coefficients } & \\
\cline { 2 - 3 } & \multicolumn{1}{c}{ B } & Std. Error & \multicolumn{1}{c}{ Sig. } \\
\hline (Constant) & 33.453 & 3.661 & .000 \\
ICT LITERACY & .356 & .081 & .000 \\
TEACHERS' & .545 & .156 & .001 \\
WORK ETHIC & & & \\
& & & \\
Variable & & & \\
Dependent: & & & \\
DISTANCE & & & \\
EDUCATION & & & \\
QUALITY & & &
\end{tabular}

Based on table IV above, the regression equation is presented as follows: $\mathrm{Y}=33.453+0,356 \mathrm{X}_{1}+0,545 \mathrm{X}_{2}+\epsilon$ follows:

The variables in the equation for multiple linear regression can be interpreted as

a) Variable regression coefficient of ICT literacy variables $(\beta 1)$ is of a positive value of 0 , 356 shows having an influence that is directly proportional to the dependent variable. This means that if ICT literacy increases, the quality of distance education will increase by the assumption of other variables.

b) The variable regression coefficient of the teachers' work ethic $(\beta 2)$ is a positive value of 0.545 indicating has an influence that is directly proportional to the dependent variable. This means that the higher the teacher's work ethic, the quality of PJJ will increase as well as the assumption of other fixed variables.

\section{b. T Test}

This study is used to determine the hypothesis accepted or rejected by comparing the significance value with the level used. Testing in this study used a significance level of $0.05(\alpha=5 \%)$. If the significance value of $\mathrm{T}<0.05$ then $\mathrm{Ho}$ is rejected and $\mathrm{Ha}$ is accepted, while if the significance value $>0.05$ then Ho is accepted and Ha is rejected.

Table 16. $T$ Test Results

\begin{tabular}{llr}
\hline \multicolumn{1}{c}{ Variable } & $\mathrm{t}$ & \multicolumn{1}{c}{ Sig. } \\
\hline ICT LITERACY & 4.401 & .000 \\
TEACHERS & 3.486 & .001 \\
WORK ETHIC & & \\
\hline
\end{tabular}


Based on the table above, it is known that some descriptions are as follows:

H1: ICT literacy on distance education quality.

The $t$ test results are worth 4,401, p of $0,000<0.05$ then $\mathrm{H} 0$ is rejected and $\mathrm{H} 1$ is accepted or can be interpreted that the ICT literacy variable has a significant effect on the distance education quality.

$\mathrm{H} 2$ : Teachers' work ethic on distance education quality.

The the t test results of 3.486, $\mathrm{p}$ of $0.001<0.05, \mathrm{H} 0$ is rejected and $\mathrm{H} 1$ is accepted or can be interpreted that the teachers' work ethic has a positive effect on the distance education quality.

\section{c. $\mathbf{R}^{2}$ (Determination Coefficient)}

The coefficient determination test results are as follows:

Table 17. Coefficient Determination Test Results

\begin{tabular}{lcrr}
\multicolumn{4}{c}{ Model Summary $^{\mathbf{b}}$} \\
\hline Model R & R Square & $\begin{array}{c}\text { Adjusted R } \\
\text { Square }\end{array}$ \\
\hline 1 & $.362^{\mathrm{a}}$ & .131 & .122 \\
\hline a. Predictors: (Constant), TEACHERS' \\
WORK ETHIC, ICT LITERACY \\
b. Dependent Variable: DISTANCE \\
EDUCATION QUALITY
\end{tabular}

The R2 test was obtained by a result of 1.22 , this shows that the ICT literacy variables and the teachers' work ethic in influencing the quality of education quality remotely by $12.2 \%$. While the remaining 87.8 is determined by variables in addition to the ICT literacy and the teachers' work ethic such as the quality of network services and the ability of the teachers in delivering distance education-based learning facilities.

Online teaching during the Covid-19 pandemic has accelerated the integration of information and communication technology (ICT) which greatly affects the distance education quality. The results of this study are in line with the researches that have been done by (Calle-ramirez \& Tumbes, 2020), (Lin \& Shek, 2021), (Lauret \& Bayram-Jacobs, 2021), (Hordatt Gentles \& Haynes-Brown, 2021) dan (Gornik et al., 2020).

(Chen et al., 2020), (Batez, 2021) and (Alasmari, 2021) conducted study on how to improve teachers' work ethic in order to develop the learning quality They investigated the teachers' involvement in enhancing the quality of distance education. Various studies demonstrated that the Pandemic Covid 19 facilitates online education delivered by learning facilities customised to students' needs. 


\section{Conclusion}

Based on the major objectives, the following conclusions are drawn in this study:

1. ICT literacy contributes significantly to the distance education quality. It is evidenced from the $t$ test result of 4,401, $\mathrm{p}$ of $0.000<0.05$.

2. Teachers' work ethic represents a significant positive contribution in the distance education quality. It is confirmed using the $t$ test of 3,486 , $p$ of $0.001<0.05$.

3. ICT literacy and teachers' work ethic simultaneously affect the distance education quality by $12.2 \%$. It is verified by the $\mathrm{R}^{2}$ test result of 1.22 .

Recommendations based on the study's results can be considered as a reference for implementing teachers' ICT skills training, as well as a critical foundation for for the methodical construction, enhancement, and sustainability of distance education.

\section{References}

Alasmari, T. (2021). Learning in the COVID-19 Era: Higher Education Students and Faculty's Experience with Emergency Distance Education. International Journal of Emerging Technologies in Learning (IJET), 16(09), 40. https://doi.org/10.3991/ijet.v16i09.20711

Bachtiar, I., \& S, A. N. (2008). Ethos (Jurnal Penelitian dan Pengabdian M asyarakat): 131-138. Penelitian Dan Pengabdian Masyarakat, 131-138.

Batez, M. (2021). ICT skills of university students from the faculty of sport and physical education during the COVID-19 pandemic. Sustainability (Switzerland), 13(4), 1-13. https://doi.org/10.3390/su13041711

Calle-ramirez, X. M., \& Tumbes, U. N. De. (2020). adolescents climate and behaviour in. 19(4), 172-178. https://doi.org/10.17051/ilkonline.2020.04.119

Chen, T., Cong, G., Peng, L., Yin, X., Rong, J., \& Yang, J. (2020). Analysis of user satisfaction with online education platforms in china during the covid-19 pandemic. Healthcare (Switzerland), 8(3). https://doi.org/10.3390/healthcare8030200

Gornik, B., Dežan, L., Sedmak, M., \& Medarić, Z. (2020). DISTANCE LEARNING IN THE TIME OF THE COVID-19 PANDEMIC AND THE REPRODUCTION OF SOCIAL INEQUALITY IN THE CASE OF MIGRANT CHILDREN TT Reprodukcija družbene neenakosti priseljenih otrok med poučevanjem na daljavo $\mathrm{V}$ času pandemije covid-19. Druzboslovne Razprave, 36(94/95), 149-168. https://www.proquest.com/scholarly-journals/distance-learning-time-covid-19pandemic/docview/2509367959/se-2?accountid=49069

Herliandry, L. D., Nurhasanah, N., Suban, M. E., \& Kuswanto, H. (2020). Pembelajaran Pada Masa Pandemi Covid-19 [Learning at the Covid-19 Pandemic Era]. JTP Jurnal Teknologi Pendidikan, 22(1), 65-70. https://doi.org/10.21009/jtp.v22i1.15286

Hordatt Gentles, C., \& Haynes-Brown, T. (2021). Latin American and Caribbean teachers' transition to online teaching during the pandemic: Challenges, Changes and Lessons Learned. Pixel-Bit, Revista de Medios y Educación, 61, 131-163. https://doi.org/10.12795/pixelbit.88054

I Gde Mertha, Idrus, A. Al, Bahri, S., Sedijani, P., \& Rasmi, D. A. C. (2019). Pelatihan Pembuatan Preparat Squash Ujung Akar Untuk Pengamatan Kromosom Pada GuruGuru Biologi Di Kota Mataram [Training on Preparation of Roots Squash Tip for Chromosome Observations in Biological Teachers in Mataram City]. Jurnal Pendidikan Dan Pengabdian Masyarakat, 2(4), 454-459. 
Lauret, D., \& Bayram-Jacobs, D. (2021). COVID-19 Lockdown Education: The Importance of Structure in a Suddenly Changed Learning Environment. Education Sciences, 11(5), 221. https://doi.org/10.3390/educsci11050221

Lin, L., \& Shek, D. T. L. (2021). Serving children and adolescents in need during the covid-19 pandemic: Evaluation of service-learning subjects with and without face-toface interaction. International Journal of Environmental Research and Public Health, 18(4), 1-16. https://doi.org/10.3390/ijerph18042114

Mamahit, C. E. J. (2021). Pengaruh Pembelajaran Jarak Jauh Model Bauran Terhadap Hasil Belajar Dan Persepsi Mahasiswa [the Effect of the Blended Learning Model on Student Learning Outcomes and Perceptions]. Polyglot: Jurnal Ilmiah, 17(1), 67. https://doi.org/10.19166/pji.v17i1.2792

Mulyana, Musfah, J., Siagian, N., Basid, A., Saimroh, Sovitriana, R., Habibah, N., Saepudin, J., Maimunah, M. A., Muaripin, \& Oktavian, C. N. (2020). Pembelajaran Jarak Jauh Era Covid-19 [Distance Learning in Covid-19 Era.].

Ningrum, P. A., et al. (2020). The Potential of Poverty in the City of Palangka Raya: Study SMIs Affected Pandemic Covid 19. Budapest International Research and Critics Institute-Journal (BIRCI-Journal) Volume 3, No 3, Page: 1626-1634

Prasasti, S. (2017). Etos Kerja dan Profesional Guru [Teachers' Work Ethic and Professionalism]. Jurnal Ilmiah Penjas, 3(2), 74-90. http://202.91.10.29/index.php/JIP/article/view/589/520520522

Purwanto, A., Pramono, R., Asbari, M., Santoso, P. B., Wijayanti, L. M., Choi, C. H., \& Putri, R. S. (2020). Studi Eksploratif Dampak Pandemi COVID-19 Terhadap Proses Pembelajaran Online di Sekolah Dasar [Exploratory Study of Covid-19 Pandemic Impact on Online Learning Processes in Elementary School]. EduPsyCouns: Journal of Education, Psychology and Counseling, 2(1), 1-12. https://ummaspul.ejournal.id/Edupsycouns/article/view/397

Sihombing, E. H., Nasib. (2020). The Decision of Choosing Course in the Era of Covid 19 through the Telemarketing Program, Personal Selling and College Image. Budapest International Research and Critics Institute-Journal (BIRCI-Journal) Volume 3, No. 4, Page: 2843-2850.

Sugiran, S., Daulay, P., Zaman, B., Effendy, F., \& Amalia, L. (2016). Evaluasi Tutor Online untuk Meningkatkan Kualitas Layanan Tutorial Tatap Muka pada Pendidikan Jarak Jauh [Evaluation of Online Tutors to Improve The Quality of Face-to-Face Tutorial Services in Distance Education]. Journal of Information Systems Engineering and Business Intelligence, 2(1), 1. https://doi.org/10.20473/jisebi.2.1.110

Sutama. (2019). Metode Penelitian Pendidikan: Kuantitatif, Kulitatif, PTK Mix Method, R\&D [Educational Research Method: Quantitative, Leather, Class Action Research, Mixed-Method, $R \& D$ ]. Sukoharjo: CV. Jasmine

Yuliani, Revina, 2021. Dampak Covid-19 Pada Masyarakat Dan Efek Terhadap Pembelajaran Online Pada Anak Usia Dini [Covid-19 Impacts on Society and Effects on Online Learning in Early Childhood]. Institut Agama Islam Negri (IAIN) METRO 